\title{
Evaluation of the Eye Lens Method for Age Determination in Sika Deer ${ }^{1}$
}

\author{
George A. FELDHAMER \& Joseph A. CHAPMAN
}

\begin{abstract}
Feldhamer G. A. \& Chapman J. A., 1980: Evaluation of the eye lens method for age determination in sika deer. Acta theriol., 25, 18: 239 - 244 [With 1 Fig.].

A significant curvilinear correlation between lens weight and age was obtained for 100 sika deer (Cervus nippon $\mathrm{Te} \mathrm{mm} \mathrm{in} \mathrm{k}, 1836$ ). The range of lens weights for each age class was distinctive for calves and yearlings only. Although age estimation by eruption and wear of dentition is currently more feasible, the eye-lens method may eventually be used to assign sika deer to more precise age categories.

[Appalachian Environmental Lab., Center for Environmental and Estuarine Studies, University of Maryland, Frostburg State College Campus, Gunter Hall, Frostburg, Maryland 21532, USA].
\end{abstract}

\section{INTPRODUCTION}

Since the initial use of the eye lens technique to estimate age of Sylvilagus floridanus (Lord, 1959), the method has been evaluated for a variety of mammalian speciels ( $F$ r i e $\mathrm{d}$, 1968). Here we report its feasibility to estimate the age of sika deer (Cervus nippon). This spercies is native to Japan and east-Aisia and has been introduced into numerous regions, including the United States, the British Isles, continental Europe, and New Zealand (F e l d h a me r, in press). Within many areas of their introduced range, sika deer populations have become sufficiently establisheid to be managed as game animals or pests.

\section{METHODS}

Lenses were collected from sika deer at deer check-stations from 25 November through 2 December 1978, in Dorchester County, Maryland. Samples also were obtained during this period from hunting camps in the area. The dressed weight of animals brought to check-stations was determined; sex was recorded for all deer and either the skull or a mandible was collected. All lenses were obtained within 12 hours of death. Eyeballs were removed intact and placed in $100 \mathrm{ml}$

1 This is Contribution Number Appalachian Environmental Laboratory, Center for Environmental and Estuarine Studies, University of Maryland and Federal Aid to Wildlife Restoration W-49-R-3 to Maryland. 
of 10 percent buffered formalin for 9 to 16 days. Lenses were not washed following removal from the eyeball. Lenses were oven-dried in glass dishes for 7 days at $37^{\circ} \mathrm{C}$. They were removed and cooled in a dessicator for 1 hour, and weighed to the nearest $0.1 \mathrm{mg}$ on a Mettler H35AR balance.

Because known-age sika deer were not available as a standard, comparative age of deer was based on the eruption and wear patterns of mandibular dentition. For consistency, one of us (G. A. F.) made all the age estimations. Age classes were determined according to criteria established by Duff (1969) for sika deer and by Lowe (1967) for red deer (Cervus elaphus). Because they are taxonomically similar and frequently hybridize (L ow e \& Gardiner, 1975), the criteria established for red deer are believed to be applicable to sika deer (K i d d i e, 1962; Lowe, 1977 and personal communication). The age class categories established by Lowe (1967) are retained here for consistancy. Because parturition in sik.a deer in Maryland predominately occurs from May through June, and all animals were collected during a 1 week period, the age classes closely correspond to the following absolute ages: age class $0=6-7$ mo. (calves); age class $1=18-19$ mo. (yearlings); age class $2=30-31 \mathrm{mo}$. (adults); and so forth.

Data were analyzed on a Univac 1004 computer using programs from the Statistical Package for Social Sciences (SPSS).

\section{RESULTS AND DISCUSSION}

Eye lensels were collected from 51 males and 49 females, ranging in age from calves to age class 9 . The majority of animals (70 percent) were calves or yearlings. The mean difference in weight beitween left and right lenses from each animal was 2.4 percent for males and females. However, because this difference ranged up to 8.9 percent between pairs of apparently undamaged lenses, all analyses were conducted using the heavier of the two lenses.

Both linear and curvilinear least squares regression models were fitted to the data, with lens weight as the dependent variable. The best predictive model was obtained with $\hat{y}=a+b \log _{10} X$. The actual form of the inderpendent variable $X$ was (age class +1 ), to eliminate computing $\log _{10} 0$ for calves. The relationship between lens weight and age was computed independently for males and females. The data from age class 0 were used in both male and female analyses because sex could not be determined for calves, either on the basis of pedical development or other cranial characteristics. There was no significant difference between lens weight and age for males and females of the same age class $(F=0.125 ; P<0.99)$. Therefore, the data were combined and the relationship of lens weight to age derived was $\hat{y}=266.46+390.38$ $\log _{10}(X+1), r^{2}=0.95 ; P<0.001$ (Fig. 1). Longhurst (1964) aliso found the model $\hat{y}=a+b \log _{10} X$ best represented the relationship between eye lens weight and age of black-tailed deer (Odocoileus hemionus columbianus), although a significant difference existed between sexes. 
It is apparent that the greatest difference in lenis weights of sika deer occurred between calves and yearlings. No overlap in ranges of lens weights existed between these age classes; mean lens weight increased 30.6 percent from calves to yearlings. Overlap did occur between yearlings and age class 2 , and between most other adult age classes. Lenses of sika deer apparently continued to increase in weight through age class 9. M a ring g le (1979) found a threefold increase in eye lens weight of roe deer (Capreolus capreolus) between 1 month and $2-3$ years of age. Eye lens weights continued to increase through

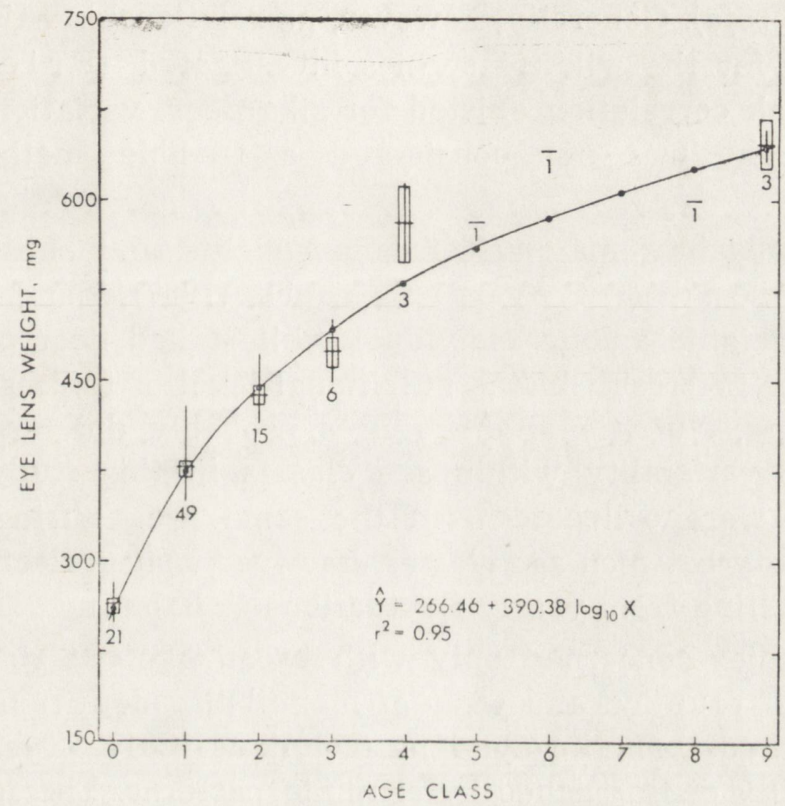

Rig. 1. Relationship of lens weight and age in sika deer.

Males and females combined. Dots represent predicted values from fitted curve; horizontal lines represent observed means; rectangles represent 95 percent confidence intervals and vertical lines represent observed ranges.

ten years of age in this species. An eye lens weight-to-age curve established for red deer ( $\mathrm{M}$ a r ing g e le, 1979) is similar to that for sika ideer. However, his sample size (19) was insufficient to demonstrate significant differences between age classes. In most of the studies summarized by Friend (1968) on white-tailed deer (Odocoileus virginianus), overlap between age classes limited the usefulness of the lens weight technique.

A relatively weak correlation existed beitween lens weight (dependent variable) and body weight for both sexes. Calves were excluded from 
this analysis because sex could not be deltermined. For males this relationship was represented by $\hat{y}=192.18+3.95 X\left(r^{2}=0.55 ; P<0.001\right)$, and for females by $\hat{y}=137.88+6.21 X\left(r^{2}=0.46 ; P<0.001\right)$. For the same body weight, females had a significantly greater corresponding lens weight than males $(F=15.60 ; P<0.001)$. This was because of the sexual dimorphism evident in sika deer; like most cervids, males are larger than females (B r o m e ly, 1956; Kid d i e, 1962). Thus females that weighed the same as males were older, and their eye lenses were corresponidingly heavier. Mats chke (1963) also found a direct relationship between lens weight and body weight for the European wild hog (Sus scrofa). Generally, however, no relationship exists between theise variables for the willdife spercies investigated ( $\mathrm{F} \mathrm{r}$ e $\mathrm{nd}$, 1968). Although a weak correlation existed for sika deer, variation was large and body weight was not considered a feasible method of age determination.

Nutritional variables may affect lens weights and subs zquent age estimation. Frie nd \& S e veringha us (1967) found that variability of lens weights among individual white-tailed deer of the same age clasess were the result of the nutritional level of fetuses and young prior to weaning. Nutritional differences probably did not contribute significantly to variability within age classes in this study, however, as all animals were collected from the same area during a 1-week period. Variability between age classes, however, may reflect nutritional idifferences resulting from yearly fluctuations in habitat.

For field studies concerned only with broad age icategories of sika deer, analysis of eruption and wear of mandibular dentition is a faster and easier method than the eye-lens technique. Calves, yearlings and adults are readily distinguished by eruption patterns. The formation of annuli in the cementum of incisors, although not a field technique, also may be used to determine yearly age classes of sika deer (K l e ve z a 1 \& Kleinenlberg, 1967; Prisjazhnjuk, 1968). Both these techniques have the benefit that large sample sizes are not needed to define age categories. However, the relationship between eye lens weight and age in sika deer may hold promise for developing more specific, narrowly differentiated age categories. This would depend upon the availability of known-age individuals. Currently, however, the eye lenis technique appears to be limited in its application towards this speries.

Acknowledgements: We thank Thomas Beaver, Bruce Taliaferro and students from the Appalachian Environmental Laboratory for assistance in obtaining study material. Dr. K. R. Dixon, Appalachian Environmental Laboratory, aided in statistical analyses. 


\section{REFERENCES}

1. Bromely G. F., 1956: Ecology of wild spotted deer in the Maritime Territory. [In: »Studies of mammals in government preserves«, P. B. Yurgenson, ed.]. The Ministry of Agriculture: $152-224$. Moscow, U.S.S.R.

2. Duff K. R., 1969: Tooth eruption as a guide to ageing Japanese sika deer (Cervus nippon) in Dorset. Deer, 2: 566-567.

3. Feldhamer G. A., (In press). Cervus nippon. Mammalian Species, 130: $1-8$.

4. Friend M., 1968: The lens technique. Transactions of the 33rd N. Amer. Wild. Nat. Res. Conf., 279-297.

5. Friend M. \& Severinghaus C. W., 1967: Influence of nutrition on eye-lens weight in deer. New York Fish and Game J., 14: 166-175.

6. Kiddie D. G., 1962: The sika deer (Cervus nippon) in New Zealand. New Zealand Forest Serv. Info. Ser., 44: 1-35.

7. Klevezal G. A. \& Kleinenberg S. E., 1967: Age determination of mammals from annual layers in teeth and bones. Academy of Science, U.S.S.R. 128 pp. (Translated from Russian, Israel Program for Scientific Translations 1969).

8. Longhurst W. M., 1964: Evaluation of the eye lens technique for aging Columbian black-tailed deer. J. Wildl. Manage. 28: 773-784.

9. Lord R. D., Jr., 1959: The lens as an indicator of age in cottontail rabbits. J. Wildl. Manage., 23: 358-360.

10. Lowe V. P. W., 1967: Teeth as indicators of age with special reference to Red deer (Cervus elaphus) of known age from Rhum. J. Zool (London), 152: $137-153$.

11. Lowe V. P. W., 1977: Sika deer, Cervus nippon. [In: »The Handbook of British Mammals". G. B. Corbet and H. N. Southern, eds.]. Blackwell Sci. Public.: 423-428. London.

12. Lowe V. P. W. \& Gardiner A. S., 1975: Hybridization between red deer (Cervus elaphus) and sika deer (Cervus nippon) with particular reference to stocks in N. W. England. J. Zool. (London), 177: 553-566.

13. M a ringgele V. F. J., 1979: Age determination of roe deer (Capreolus capreolus [L.] and red deer (Cervus elaphus L.) by means of the evaluation of the eye lens dry-weight. Ztschr. für Jagdwiss., 24: 178-182.

14. M a ts chke G. H., 1963: An eye lens nutrition study of penned European wild hog. Proc. 17th Ann. Conf. SE. Assoc. Game and Fish Comm., 20-27.

15. Prisjazhnuk V. E., 1968: Determination of age of sika deer from the lamination on the incisors cement. Bull. MOIP, Biol., 73: 51-62. [In Russian with English summ.].

Accepted, January 13, 1980. 
George A. FELDHAMER i Joseph A. CHAPMAN

\section{SOCZEWIKI JAKO WSKAŹNIK WIEKU U JELENIA SIKA}

\section{Streszczenie}

Zbadano 100 jeleni sika (Cervus nippon $\mathrm{Te} \mathrm{mmin} \mathrm{k}, 1836$ ). Uzyskano istotną krzywoliniową korelację między ciężarem ich soczewek a wiekiem. Roczniaki mają ciężar soczewek większy o $30,6 \%$ od cieląt. Soczewka zwiększa ciężar w kolejnych klasach wiekowych, choć zakresy ekstremalne mogą zachodzić na siebie (Ryc. 1). Chociaż ocena wieku na podstawie wyrzynania się i ścierania uzębienia jest częściej stosowana, metoda ciężaru soczewek może być użyta do wyznaczenia bardziej precyzyjnych kategorii wiekowych u tego gatunku kopytnych. 